\title{
THE CONCEPT OF NATIONALIZATION OF NADJ AMOEDDIN DAENG MALEWA IN SOUTH SULAWESI ON 1907-1947
}

\author{
Siti J unaeda ${ }^{1}$
}

\begin{abstract}
Theideas of Nationalismin South Sulawesi weremarked by theincorporation of national organizations that have formed branches in Makasar. Makasar was not only a city of the center of administration or the center of politics, but also as a barometer for the eastern Indoneisa areas to be a designated area of various national organizations. Sarekat Isalm was the first modern organization built in Makasar in the 1916, followed by Muhammadiyah, Assiratal Mustaqim, NU, PKI, PNI, PARTINDO, PARINDRA et cetera. Apart from being the designation of the national organization to open their chapters, in South Sulawesi have appeared regional organizations, such as the Celebes Organization, which then transformed into Celebes Party, and South Celebes Organization. Theutilization and translation of ideas of nationalism in South Sulawesi can be traces from the principles or working program for each and every organization.

Nadjamoeddin is one of the moving figures in South Sulawesi who has actively participated in the expansion of theidea of nationalism and nationality by being active in local or national organizations of political party. He has build unity in realizing the national movement through organization or local and national parties such as Celebes Organization, Celebes Party, Parindra, dan South Celebes Party. In a few of his writings and speeches he believes that in order to achieve prosperity for the whole Sulawesi people particularly and Indonesia in general, and therefore there are three important things to attain. First: The unity of any and all nations; Second: Equal education for all; and Third: A strong economic system. Three of these matters have become the important conditions to achieve a strong and independent country.
\end{abstract}

Key words: Nadjamoeddin, South Sulawesi, Celebes Party, Parindra, dan South Celebes Party

1 Siti Junaeda, M.Hum, Lecturer of History Education, Universitas Negeri Makassar. This Article has been reviewed by Prof. Dr. Nina Herlina Lubis (Padjajaran University), Prof. Dr. Susanto Zuhdi (Indonesia University), and Prof. Dr. Helius Sjamsuddin, M.A (Indonesia University of Education). 


\section{Introduction}

The $20^{\text {th }}$ century is often referred to as the modern era. Furnivall translated the century as the era of "expansion, efficiency, and prosperity" (Takashi, 1997: 35-36). One of the markings of this era is the expansion of Western education system in order to produce intellectual natives who will have been projected as government or non government staffs. The natives who had been educated abroad eventually appear as a new social group that is referred to as elite (Bottomore, 2006).

At the time, they had thought about the the idea of nationalism, and it had been transformed extensively within the community through various types of organizations and or political parties. It was through organizations or political parties that seeds of nationalism, as a motivator to determine one's fate, have emerged. Nationalism is signified as an effort to build characters in determining the fate of a nation (Khon, 1984:11).

Nadjamoeddin Daeng Malewa began his political career in South Sulawesi by joining theCelebes Unity. Dueto his competenceand capability, Nadjamoedin had been given the opportunity to lead the Makassar Branch. Moreover, he was also appointed leader of the Padoman Besar in the structure of Celebes Organization. With the other board members, Nadjamoeddin has succeeded in developing Celebes as a local and national community organization, and thus the Celebes Organization has become more dynamic. The dynamization is very obvious as the Celebes Organization has become a media to transform Nadjamoeddin's ideas of Nationalism in the South Sulawesi. This idea of nationalism was propagandized through writings in various newspapers, and also expressed through his various speeches in various forums of numerous parties.

Nadjamoeddin's choice to join the Celebes Organization was based on his interest on the objectives of this organization that is eager to advance the needs of the local people of Celebes as a progress support on a much larger scale, which is the national of Indonesia. These goals were meant to accomplish the advancement of any and all regions in Indonesia such as in J ava and Sumatera. The success of a nation is attainable upon the achievement of unity. Here is a quote of his speech:

Mencari persatoean dalam pergerakan kebangsaan, itoelahyang teroetama diamalkan oleh pemimpin-pemimpin bangsa di waktoe sekarang. Kaoem pergerakan kita di Indonesia semoeanya adalah berbesaran hati bahwa semangat persatoean indonesia soedah masoek kemana-mana, djoega pada kita di noesa selebes ini. Semangat itoe soedah melekat di atas bibir tiap-tiap orang pergerakan Indonesia, mendalam kehati tiaptiap orang Indonesia jang berdjoeang membela keselamatan tanah air dan bangsa menjadi dasar jang tegoeh bagi gerak dan terdjangnya Perserikatan Selebes...

...dan wadjib kita koeboerkan segala perasaan kekotaan, kepoelaoean dan keprovincian dan wadjib poela kita insjaf dengan seinsjaf-insjafnja bahwa kita sekalian adalah poeteri-poeteri dan potera-poetera Indonesia. 
Kota-kota seperti Makassar, Manado dll itoe hanjalah masing-masing kota kelahiran kita dan Indonesialah iboe dan negeri kita jang haroes kita tjintai, sebab nasinja jang kita makan dan airnja jang kita minoem. Djadi tidak lebih dari kewadjiban kita djika kita memperhambakan, memperboedakkan diri kita oentoek iboe Indonesia. Cinta bangsa dan tanah air haroes kita menanam dengan sedalam-dalamnja dalam hati sanoebari kita sekalian...(Suara Perdamaian, 1930)

Searching for unity in the movement of nationality is the main matter that is practiced by the leaders of our country at this moment. All groups of the movement in Indonesia are proud that the spirit of unity in Indonesia has disseminated everwhere, as well as in our region, the Celebes Island. The spirit is sealed in the mouth of every person supporting the movement of Indonesia, has gone deep into the hearts of each and every Indoensian who are fighting for the safety of our native land and nation, which have become a firm foundation for the movement and actions of Celebes Organization... ... and we must bury all kinds of feelings: urban, islanders, provincial, and we must realize that we are the daughters and sons of Indonesia. Cities such as Makassar, Manado et cetera are only each and every one's birth city and it is Indonesia that is our mother and nation that we must love, for we are eating her the rice and drinking her water. Thus it is not more than our responsibility if we shall enslave ourselves for our mother Indonesia. Loving our nation and nativeland must be rooted deeply in our hearts as the seat of the emotions, mind and soul...

Nadjamoeddin very much realized that the spirit of the movement to defend the nativeland requires the unity of any and all people. The differences of regional origins have become insignificant for discussion/argumentation in order to win the fight of nationalism. Participating in the movement is the duty of any and all people of the nation as a manifestation of the love for Indonesia.

The management of Celebes Organization was consisted of people from various backgrounds of politics and social cultural. During its development, the differences in cultural background had become the trigger of internal problems within the organization, which lead up to the conflict between "the north" and "the south". This conflict was finally terminated at a dissension, when Nadjamoeddin who was appointed as the Chairman of Celebes Organization of the Makassar Chapter had taken over and altered the party's name to Celebes Party (Barisan Kita, 1931). The change in the Makassar Chapter was also followed by the Barranglompo Chapter. Thus at the beginning of the formation of Celebes Party, it has had around 400 joint members from the Makasar and Barranglompo Chapters (Barisan Kita, 1931). For the development of the party, a few chapters were further opened such as the Surabaya Chapter on 17 J anuary 1932, the Bonthain Chapter, the Boetoen Chapter, the Palembang Chapter, and the Gerong River Chapter (Barisan Kita, 1932). 
At the time that Nadjamoeddin was elected General Chairman of the Celebes Party, the development of the party has amplified. The Celebes Party has had the same principles as the Celebes Organization. Unity and Nationalism remained to be the principles of the party, and so were the three matters that remained to be the purpose of the party, which were the unity supported equal opportunity of education for any and all citizens, independence in the economy, as well as fortification of political base as a media to achieve the objectives of the movement.

As part of an effort to develop the party, Nadjamoeddin and his friends had agreed upon merging into a larger coalition, which is becoming a member of PARINDRA. Unfortunately Nadjamoeddin was a type of person who is not easily satisfied with his achievements. Therefore, his fusing the Celebes Party that he led into the PARINDRA did not make Nadjamoeddin satisfied with what he had achieved during his enrollment. One of the main reasons of his disappointment with Parindra was when he failed the election to be a member of Volksraad for the period of 1935-1939. One of the reasons of his failure in that election was due to lack of support from some of the central board of Parindra in Surabaya, who were more inclined to nominate Ahmad Daeng Siala who, at the time, was a member of the board of Parindra in the Makassar Chapter.

Nadjamoedin's disappointment was apparent upon his decision to separate himself from Parindra, the place where he began his ideas to advance the navigation of the natives. Under his leadership, Nadjamoeddin walked out of Parindra followed by 250 people in the month of April 1939 (Harvey, 1989: 80). After he left Parindra, Nadjamoeddin immediately formed a new pary that was called the South Sulawesi Organization. The unity and nationalism remained to be the principles of the new party, which was the same as the previous parties, Celebes Party or Celebes Organization. Even though South Sulawesi Organization had held the same principles as the previous parties, however the Party firmly declared itself as a party that is loyal to the government. The declaration was stated in writing and was written on the fourth principle of the party Dalam pekerdjaan oentoek mentjapai kemoelia'an Selebes selatan, maka Persatoean Selebes Selatan bersikap loyal terhadep pemerentahan negeri (For the purpose of achieving the nobility of the South Celebes, and therefore the South Celebes Organization is loyal to the government of the nation) (Pemberita Makasar, 1939).

Thedeclaration of theSouth Celebes Organizaiton thatmadean openstatement on their willingness to cooperate with the Dutch government at the beginning has attracted many doubts from the other movements in South Sulawesi.

\section{Advancing Education for the Natives}

Nadjamoeddin uttered that his reasons for cooperating with the government is conducted in order to fight for the advancement of the people of South Celebes. The advancement fought for includes education, economy, social, and politics. 
Once the unity of the nation has succeeded, and therefore the subsequent step is to achieveequal opportunity education for any and all people. During this phase, Nadjamoeddin along with his peers such as Lindoe marsajit, Madam Lumenta, Salawati Daud, D. Th. N. Lengkong through Organization of the Teachers of the People of Celebes (Perhimpunan Perguruan Rakyat Selebes - PPRS). PPRS was an institution formed by the Celebes Organization that particularly was managing theeducation by buildinga number of national schools and courses. In a report of the PPRS, it was mentioned that at the beginning of 1930, there were only 526 students who were enrolled at Inlandscheschool (a school formed by the government), whilest 215 prospective students were declined (Suara Perdamaian, Number 2, J uly 1930 Year I, page 1) It was due to this condition that has encouraged PPRS to actively participate in the development of education in Sulawesi Selatan. A more important reason is the independence of the nation in organizing education. As Nadjamoeddin explains:

...Djikalaoe kita maoe madju, maka djangan menanti-nanti tolongannya orang lain, djikalaoe kita maoe berdiri, djoega djangan menanti-nanti sokongan dari orang lain. Hanja kepertjajaan pada kekoeatan dan kebiasaan sendiri jang akan membawa Iboe Indonesia ketempat jang kita tjita-tjita. Inilah faktor jang penting sekali dan inilah sebab-sebabnja, sampai ditempat jang ketjil-ketjil, timboelnja pergoeroean nasional. Djoega itoelah sebabnja maka PPRS berdiri di kota Makassar, ditengahtenganja rajjat Bugis dan Makassar ini.

...Djoega boekoe-boekoe yang dipakainja sehari-hari di itoe sekolahan penoeh dengan penghinaan dan merendahkan bangsa kita. Oempamanja sadja itoe boekoe dari Toean Croes jang telah tersohor di seloeroeh indonesia: "De dief" disitoe kita batja, dan soedah tentoe sadja si dief ataoe maling hanja lain perkataan sadja dengan si Inlanders. Sekali lagi sadja oelangkan, bahwa alat-alat pengadjaran di soewatoe Pergoeroean Barat penoeh dengan penghinaan terhadap perasaan bangsa kita.

If we shall wish to succeed, and therefore we will not depend upon the aid of others. If we wish to be independent, and therefore we shall not be dependant upon the support of others. It is only through believing in our own strengths and customs that will bring our Mother land Indonesia to the place we have been wishing for. These are the important factors and these are the foundations, for even up to the smallest places, national schools shall emerge. Therefore, it also the reason PPRS was born in the city of Makasar, in the middle of the people of Bugis and Makassar.

... And also amongst the books that are read daily in schools are contained with degradation and humiliation of our nation. For instance, if those books derive from Mister Croes who is renown throughout Indonesia: "De dief" where we read, and certainly the dief or thief is only a word to theInlanders. Let me remind you that the teaching equipment in any Western school is full of degradation of the feelings of our nation. (Barisan Kita, Number 2, 
February 1931 year I, page 4)

\section{Furthermore he explains:}

Pergoeroean nasional haroes memakai kebangsaan sebagai ia poenya pundament; artinja pedjaran2 jang diberikan kepada moerid2 "haroes tjotjok" dengan kehidoepan dan penghidoepan kita.

Djikalaoe pergoeroean2 ta' memakainja ini, soedah tentoe anak akan tinggal asingterhadap kalangannja sendiri (djadi sama sadja dengan boeah pendidikan Barat) dan ini berarti bahwa sang anak tadi akan ta' mengetahoei keperloeannja biarpoen keperloeannja lahir ataoe bathin ataoe lain perkataan perasaan kebangsaan akan tinggal di bibir sadja.

The National schools must use nationality as a fundamental value, meaning the subjects taught to students "must comply" with our lives and livelihood.

In the event that our schools do not comply with this value, and therefore our children with feel foreign amongst their own kind (thus, it is similar to the fruits of Western education) and this means that the children will not comprehend the needs, either the birth needs, or the inner self, or in other words, nationality will only be lip service. (Mars, 1931: 3)

This statement more affirmed the importance of providing teaching suitable to the needs of the nation, as it is strongly related with the strengthening of nationalism for the natives. The PPRS believes that the persons who understand the most of what we need is no other than ourselves. It is very clear that the mission of the PPRS is to achieve the unity of the nation with the support of the equality of education.

The PPRShas opened three types of morning schools, which were Elementary School, which was a school of class II with additional subject of Dutch language and boekouden, the Elementary School Addition (Perguruan Rendah Penambah - P.R.P) or equal to Schakelschool with additional subject English language and boukhouden, and the General Elementary School (Perguruan Rendah UmumP.R.O) or equal to HIS with additional subject of English and boukhouden. For late afternoon classes, School of Assistant Teacher or Normaalcuursus was opened and conducted for two years, and had available a few short courses such as Dutch language courses, English language courses, trade courses, stenografie, dan Cuursus Algameene Ontwikkeling (General Knowledge Courses).

The material given was quite various, but history material was given quite big portion. The materials was including Babad Indonesia thoughtbyL. Marsajit, State Governance Regulation (Aturan Pemerintahan Negeri) by H.A. Lumenta, India, Egypt, Tiongkok and Philippines Movement (Pergerakan India, Mesir, Tiongkok, dan Pilipina) by Lengkong, and Summary of West Movement of Fransche Revolutie Influence (Pergerakan Barat atas Pengaruhnya Fransche Revolutie) by Nadjamoeddin. In addition to teaching European History, by his partners, Nadjamoeddin was trusted to teach Dutch language as a result that, compared with his friends and partners, he is considered as fluent in Dutch. Nadjamoeddin concern in education in South Sulawesi was widely 
spread to the outermost area of South Sulawesi which is Buton, as said:

Atas oesahanja saudara Nadjamoeddin wakil ketua Padoman Besar maka PS dan PPRS Tjabang Boeton telah didirikan. Inilah adalah soeatoe nationaledaad dari saudara Nadja terseboet karena dimasa ia mengasoh (verlof) ke Boeton ia pergoenakan waktoenja dan tenaganja oentoek memadjoekan bangsa dan tanah air. Akan djasanja itoekita haroes djoenjoeng tinggi".

As a result of the effort of Nadjamoeddin, thevicechairman of Padoman Besar, PS and PPRS, Boeton Branch, had been established. This is nationalism spirit of Nadja because when he mengasoh to Boeton, he used his time and ability to develop and build his nation. As a result of his service, we has to honor it. (Barisan Kita, Number 5-6, J uly-August 1931)

Thecommitment of Nadjamoeddin to develop education for bumiputera was high. It is proven by his friends and partners selecting him as director of PPRS replacing Mistress Ticolau. At that time, PPRS condition was bad, especially its financial. Nadjamoeddin as the new director must immediately settle the PPRS loan using his personal fund. The loan issue was for carpenters and house rent of f.110. This action was obtained positive appreciation from his friends and partners and also the newly established verification committee.

Kami Verificatiecommisie berpendapatan pada waktoe pemeriksaan, bahwa verantwoording beliau (Nadjamoeddin) itoe dikerdjakan dengan saksamanja dan sebagaimana moestinja, sehingga kita menjatakan, bahwa pekerdjaan orang jang sedemikian itoe, jang sekian berat tanggoengannja, serta dia tiada mengeloeh dan dikorbankannja temponja jang akan dipakainja oentoek bersenang-senang, serta tenaganja terhadap kepada bangsa dan tanah airnja, maka ta' dapatlah rasanja kita menilainja, apalagi pekerjaan itoe, pekerkaan jang semoelia-moelianja.

(We, Comission of Verification had an opinion during examination that his veranwoording (Nadjamoeddin) was performed accurately and accordingly and therfore we said that the work, which is hard to be borne and he had no complain also used his leisure time and ability for his nation and country, can be praised. Morover, the work is very valuable) (Barisan Kita Number 5,6,7 in the month of March, April, and May 1932 Year II Page 2, 3)

Nadjamoeddin concern to develop and build education for his country and nation could also be seen from his willingness to develop education especially education for women. The school was aimed to give skills for any woman in South Sulawesi. This school was addressed to the alumni of Volkschool whose 
educationallevelwas3years (onderbouw), and alumni of HIS or (Schakelschool) whose educational level was 4 years (bovenbouw). 4 years educational level was given: 1) household affairs (huishouddelijke vakken); 2) sewing and embroidery (handwerken); 3) school teachers (Frobel-onderwijzeres). Based on his efforts, Nadjamoeddin were succeeded to gather approximately 64 students who will join 3 years class (onderbouw) and 70 students who will join 4 years class. Nadjamoeddin plan was described in detail and completed by the curriculum to be used (Macasar Announcer, Saturday February 10 1940, Year XXXVIII, Number 34 , second sheet).

Strong willingness to develop women in this country was not only showed in his speech and writings. Nadjamoeddin has practiced it in his family. He gave opportunity to his wife, Mrs. Hadidjah to participate in movement organization both in Selebes Union or Selebes Party. Mrs. Hadidjah was also active on motivating the South Sulawesi women by participating in Istri Selebes Union established on April 1931 in Makassar. In her writing, Mrs. Khadidjah said:

Pergerakan kaoem isteri adalah pergerakan nasional jaitoe oentoek membakti pada keboetoehan nasional, pada rajat dan tanah air Indoenesia. Kita perempoeanjang lebih bisa merasakan kesengsaraan dan kebingoengan dan jang lebih-lebih bisa merasakan ketjintaan pada ra'jat. Wahai para perempoean, korbankanlah perasaan-perasaanmoe djikalau itoe bertentangan dengan pekerdjaan nasional. Koebankanlah ia oentoek keperloean oemoem karena djika tidak begitoe tersia-sialah teriakan tentang ketjintaan kepada bangsa dan tanah air. Koeatkanlah barisan Sarekat Isteri Selebes soepaja dapat kita mempeladjari dan menjelidiki keadaan-keadaan yang boesoek oentoek memperbaikinja. $\mathrm{M}$ o e d a $\mathrm{h}$ moedahan Iboe Indonesia memperlindoengikita sekalian dan membri kebidjaksanaan dan ketegoehan soepaja kita bisa membakti dengan sempoerna padanja.

Wives movement is the national movement for dedication to Indonesian national needs, people and nation. Women can feel the confusion and misery as well as love for the people.

Dear all women, sacrifice your feelings if it is contradictory to national work. Sacrificing them for the purpose of public interest. Because if you don't sacrifice them, the screaming of the people concerning their love to nation will be useless. Strengthening Selebes wives Union lines in order to learn and investigate theconditions to beimproved in the future. Hopefully, Indonesian Mother protects us and gives us wisdom and constancy, and therefore we can dedicate ourselves perfectly to it (Nadjamoeddin, Nadjamoeddin, Taman Keputrian, Barisan Kita, No.3-4, 15 and 29 February1932, Year II, page. 2) 
The statement mentioned hereinabove shows that Nadjamoeddin has given a space for his wife to be active in movement world. This is the form of Nadjamoeddin seriousness in developing women especially South Sulawesi.

\section{To Build the Base of People’s Economy}

Nadjamoeddin sees that when the unity fully supported by equitable education has been fulfilled, and therefore the next process will be strengthening the people economic basis. Economy basis becomes movement support in order to reach theindependency for the establishment of middendstand class. Therefore, Indonesia becomes a big and independ ent nation. In a meeting of Protest-Vergadering, Nadjamoeddin explains that capital factor (economy) becomes the main support of any country. He explained as follows:

...lihatlah sadja pada Amerika Pendoedoek aseli dari Amerika itoe adalah bangsa Indian, akan tetapi bangsa Indian itu terdapat lagi di kota-kota Amerika, hanja di goenoeng-goenoeng sadja, oleh sebab bangsa-bangsa Europa jang moela-moela datang disitoe sebagai tamoe soedah mendapat tanah dan oleh kekoeatan kapitaal maka dalam peperangan economi bangsa Indian kala dan terpaksa lari pergi di goenoeng. Demikianpoen djoega keadaan di Kanada dan di Australie. Djoega keadaan demikian akan terjadi di Indonesia ini, kalau hak tanah kita diberikan pada bangsa lain, soedah tentoe djoega anak tjoetjoe kita oleh kerna kekoerangan kapitaal akan terpaksa tinggal di goenoeng dan bangsa lain jang lebih koeat economienja akan tinggal di kota-kota negeri kita. Oleh kerna itoe, soepaja keadaan demikian tidak akan terdjadi di negeri kita ini, maka soedah pada tempatnja kalau kita menolak permintaan kaoem Indo itoe.

... see America. The origin people of America is Indian, but Indian is no longer found in America cities, they are only found in the mountains. Therefore, European people who was first came there as guest already has some land. Based on capital power,Indian people was lost in economic war and they must go from the moutains. Canada and Australian people have the same condition. That condition will occur in Indonesia in the event that our land rights are given to other nation. Our children and grandchildren will live in mountains and other nations having stronger economy will love in our cities. And therefore, in order to prevent such condtion, it will be appropriate to refuse the willingness of Indo people (Barisan Kita, Number 2, 30 J anuary 1932 year II ). 
Nadjamoeddin considers that capital function is very important, and therefore it must be owned by a nation. Based on the strong capital, nation can authorize and also expel other nation, it can be otherwise. Based on his opinion, it will be natural if he considers that economy basis is the obliged requirements must be fulfilled by a big nation. According to Nadjamoeddin, in order to reach political freedom, a nation must first achieve economical freedom.

\section{To develop Country Service}

When he was active in PARINDRA, Nadjamoeddin was given opportunity to realize his idea to develop the country economy. Nadjamoeddin started it with his effort to develop the country navigation which is monopolized by Koninklijke Paketvaart Maatschappij (K.P.M.) (Barisan Kita, Number 2, 30 J anuary 1932 year II). KPM Monopoly policy was the same as the high tax implementation causing lost for the country. This policy was not only caused lost for the country navigation but also Chinese small ships entrepreneur. Other policies were every navigated shop were obliged to pay bail authority expense which was previously obliged to pay $40 \%$ expense of the loaded goods (Dick, 1990: 18-22). Even though the ship owner has fulfilled the obligation by paying the high expenses to K.P.M., insurance guarantee to the goods lost or damage during the navigation was remain unavailable. The bail will be considered as lost and included I $\mathrm{n}$ the Government cash. As said in a newspaper:

Menjaingi KPM memang bisa dijalankan, tetapi tidak bisa tahan lama, selama poebliek ataoe saudagar2 tiada bersatu hati membantoe oesaha itoe. Kedjadianjang seroepa di atas boekan sadja terdjadi disini akan tetapi dimana-mana tempat, dimana orang Mentjoba menyaingi K.P.M. tetapi kesoedahannja terpaksa toendoekdan K.P.M. mengibarkan bendera kemenangan.

Competing KPM is able to be performed, but it would not everlasting when public or people was not united to assist the effort. The same incident as mentioned above is not only occurring here but everywhere where people try to compete K.P.M. However, at the end, they must be abide with K.P.M and K.P.M will fly the victory flag.

Facing the condition mentioned above, Nadjamoeddin established Roekoen Pelayaran Indonesia (ROEPELIN) on November 1935. Roepelin has the following objectives:

1. Akan bekerdja bersama-sama oentoek mendapat moeatan dengan oepahjang sebaik-baiknja. 
2. Akan berdaja oepaja dengan djalan jang sah oentoek mendapat keringanan dari beban-beban pelajaran.

3. Akan menjiarkan pengetahoean tentang pelajaran dan jang berhoeboengan dengan itoe.

4. Akan menggiatkan nafsoe anggautanja oentoek menyimpan oeang pada perserikatan.

5. Menolong anggautanja memberi pindjaman dengan djalan jang moedah dan berarti pendidikan oentoek mentjapaikan maksoed-maksoednja jang mendatangkan faedah.

1. To cooperate in order to obtain the load with the best fees.

2. To make an effort based on the legal way to obtain compensations of the study loads.

3. To share the knowledge concerning the study and any matters related to it.

4. To activate the passion of its member to save money in the union.

5. To assist the members on giving loan with easy way and it means education to reach the objectives bringing in some benefit (Soeara Parindra, Number 1, J anuary 1936, page. 19-20).

After Roepelin is established, the country shipping and navigation is developed. It is including the shipping route. It becomes more and wider. The progress reached including the shipping travel time and the expansion of reached area. The shipping travel time which was only performed during east wind season (between April to November), is no longer based on natural condition.

“..mereka adalah djoeragan La Djato dengan perahunya Toeroetjinna Kadjoeara telah berangkat dari Selebes dalam pertengahan boelan desember menoedjoe ke Borneo..."

...Djoeragan Zain dengan perahoenja Tjinna Mattola, telah mentjoba poela berangkat ke Soerabaja dalam moesim barat...

...Djoeragang Tahir dengan perahunja "Senang Hati" tiada hendak ketinggalan poela melakoekan pelajaran dimoesim barat dan sampai ketoedjoean hanja dalam tempo 25 hari..."

“... They are La Djato with his ship, Toeroetjinna Kadjoeara, has departed from Selebes in the middle of December to Borneo..."

...Zain with his ship, Tjinna Mattola, has departed to Surabaya in west season

...Tahir with his ship, "Senang Hati" also shipped in west season a n d arrived in its destination within 25 days ..." (Roch Pelajaran di Soelawesi Selatan", Soelawesi, Number 3, 21 April 1934 Year I, Page 4)

The improvement was not only on shipping and navigation but also on transportation fleet quantity. The ship having 800 to $1000 \mathrm{lbs}$ from 
only less than ten ships became more than 10 ships. The ships having capacity 500 to 700 lbs has became hundreds. The most significant change was the drastic increase of ships having $300 \mathrm{lbs}$ to 1000 lbs. The number is not less than 1000. In addition to the changes, other achievement by Nadjamoeddin was the joining of 200 Bugis and Makassar ships in Roepelin organization. This ship can be organized and controlled maximally under the control of Roepelin.

\section{Pioneering the Establishment of the Cooperative}

Besides advancing the bumiputera shipping, Nadjamoeddin also develop the base of people's economy which is the cooperative. He has started this program during his active time in PARINDRA by coaching villages to become the cooperative village. He developed 54 cooperative villages in Surabaya. However, the programme does not work well. When he moved to makasar, Nadjamoeddin re-develop cooperation by developing Minasa badji (in Makassar a hope to obtain a good result) where he became the chief. As a new develop cooperation, Minasa Badji had no capital. Therefore Nadjamoeddin as the leader made efforts to get the government's help. This effort succeeded and he received subsidy from the government and could obtain the omzet in the amount of $\mathrm{f} 24$. 000 . He said:

“.. bagimana baeknja bercooperatieitoedan apa goenanja Bank Cooperatie, sebagai boektinja Cooperatie itoe (Koperasi Minasa badji) jang di Makassar ini mampoe memberi pindjam sebanjak lima roepiah kepada tiap2 pedagang ketjil oentoek dipake mendjadi modal soepaja bertambah madjoe peroesahannja dan semakin banjak diperoleh keoentoengan... pedagang2 di negeri Belanda sampe ada poela kaoem pendjoeal sajoer jang mendapat soebsidi...".

".. how to do a good cooperation and what is the use of the Cooperative Bank. as a proof the Cooperatie (Minasa badji Cooperative) here in Makasar is able to provide five Rupiah loan to every small traders for their capital to advance their business and gain more profit. .the traders of Netherland and even the groceries receiving the subsidy (Pemberita Makassar, Wednesday 7 December 1939, number 256, Second sheet).

By developing cooperative it is hoped to improve the life quality and business particularly for traders with small capital. Capital distribution for small traders is helpful to maintain their existence.

Besides Makassar, Nadjamoeddin also pioneering the cooperative development in Selayar as the region of the biggest copra procedure in South Sulawesi. The cooperative establishment was as a solution of the decrease of copra trading from Selayar to Makassar. 
“..dari kapal kelihatan dengan njata bahwa poelaoe Saleier itoe penoeh dengan pohon kelapa anak negeri. Pada seorang pedagang anak negeri, jang saya tahoe banyak berdagang kopra dan lain-lain hasil anak negeri poela, jang senantiasa mengirim dengan perahoe lajar, djoega ke poelaoe Djawa, saja telah tanjakan apakah sebabnja, maka tidak ada kopra sekarang jang keloear dari poelaoe Saleier, sedang dahoeloe saja tahoe beriboe2 karoeng kopra jang dikirim ke Makassar, tidak sadja dengan perahoe, tetapipoen dengan kapal djoega..."

...it's visible from the boat that Selayar island has many coconut trees of the natives. I asked a local seller, who I considered to have sell many copra and other things, that often exporting things by sailboat, even to J ava island, why there is no copra to be exported out, whilein the past thousands sacks of copras were exported to Makassar, not only by boat, but also by ship (Pemberita Makassar, Tuesday 4 Februari 1941, Number 26 Second sheet.).

The copra traders of Selayar had difficulties in fulfilling the minimum quote required by the Kopra-Fonds of Makassar. This condition result in the emergence of many copra broker. The copra broker used this condition to gain high profit. The broker buying price from the farmers was f 1,50 per $100 \mathrm{~kg}$ and they sold it in a high price Understanding this condition, Nadjamoeddin offered a solution to establish a cooperative.

Pada tempatnja sekali kalau anak negeri jang mempoenjai pohon kelapa itoe, mengadakan organisasi jang beroepa productie-cooperatie, soepaja dengan djalan bekerdja bersama-sama, segala kopra mereka dikoempoelkan dan didjoeal bersama-sama langsung ke kopra-fonds di Makassar, sehingga dengan djalan ini, maka soal 25 ton itoe tidak akan mendjadi halangan lagi.Dengan organisasi koperasi sebagai itoe, maka mereka akan mendapat harga jang lebih tinggi daripada sekarang dan bisa poela memperdengarkan keberatan-keberatannja pada jang berwadjib.

It would be better if the owners of the coconut trees form an organization of productive-cooperative, so they can work together to gather all of their copras and sell it collectively directly to the Kopra-Fonds in Makassar. Therefore, I hope this way the 25 tons quote problem would not be an obstacle anymore. By the cooperative organization to support this plan, they may get higher price than it is now and they may complain to the authorized party (Nadjamoeddin, 1941).

The purpose of the cooperative development was to minimize the loss occurred to the copra farmers. The copra farmers was expected to work together in gathering the copra to meet the minimum standard defined by the KopraFunds of Makassar. The same condition also happened in Gowa, Nadjamoeddin 
revitalized the unproductive cooperative that initially formed by Daeng Boeang (a Gowa aristocrat) was revitalized by Nadjamoeddin and ita was named the "Tamalate" cooperative (Nadjamoeddin, 1941).

Nadjamoeddin consentration in the development on the base of the people's economy was continued until after the independence era 1945. When he was occupied as the prime minister of NIT and as the economy minister, the development of people's economy was the important policy in his work program.

\section{Carrying the Federal Notion as the Form of Indonesia Constitutional}

When he was elected as the NIT Prime Minister concurrently as the Economy Minister, in his political manifestation Nadjamoeddin conveyed the advantageous of federal nation and several matter associated to his responsibility as the economy minister. He considered that the federal form was the solution for Indonesia that consist of many islands. In addition, federal was also considered as the evaluation and improvement of the centralistic constitution applied by the Dutch East Indies' government. The far distance between the central and the region might result in a significant effect of the autonomy that could be handedover to the region.

Nadjamoeddin had strong beliefs on all advantageous of the federal constitution akan segala kelebihan dari bentuk ketatanegaraan yang federatif ini begitu kuat. According to him, Federation was the absolute requirement to actualizing the dream of a nation independence. Independent in politic, moreover in economy to provide welfare for its people. This was conveyed in the conclusion part of his political manifestation:

Akan tetapi sekali lagi pada penoetoep pemandangan ini, pemerintah berkehendak memberitahoekan bahwa sebagai sjarat moetlak oentoek mewoedjoedkan toedjoean dan tjita2 jang dianoetnja itoe ialah bentoek Negara jang federatief. Tidak ada cara jang lain jang bisa melindoengi kita terhadap pemeliharaan jang tak sepertinja jang akibatnja memang telah lama kita alami itoe. Tak ada lain tjara lagi jang memoengkinkan kita akan meniadakan segala kekoerangan2 kita di atas berbagaibagai lapangan, tak ada lain tjara oentoek mengembangkan soesoenan perekonomian dan keinginan2 kita jang menghendaki kehidoepan dan penghidoepan sesoeai dengan perasaan dan kebiasaan2 sendiri, tak ada poela lain tjara jang dapat mendjaga kita terhadap bahaja jang pasti akan menarik kita kedalam kekatjaoean ekonomi disoeatoe bagian, jang kita sendirisoedah mentjegahnja dengan melaloei djalan2 janglegaal. Dan oleh karena ini telah mendjadi kejakinan pemerintah jang sesoenggoehnja sangatprinsip ini akan melipoeti seloeroeh kebidjaksanaannja maka ia menaroeh kepertjajaan sepenoeh2nja bahwa didalam tindakan2nja ia 
akan mendapat sokongannja bahagian jang terbesar dari golongan2 bangsa di Indonesia Timoer dan daripada badan jang mewakilinja itoe.

However to close this view, the government will explain the absolut requirement to actualizing the goal and dream it is believed is the Federative constitution. No other way may protect us from the inappropriate governance that effect has been felt since long time ago. No other way that enable us to eliminate all of our deficiency on many things, no other way to improve the economy arrangement and our wishes for the life and livehood as we like, no other way that can protect us from the danger that will attract us to the economical trouble in one part, that we have prevented it through the legal ways. Therefore, the government belives that this principal will be fully supported by the people of East Indonesia and its representative (Nadjamoeddin, 1947).

By the federal system, Indonesia will consist of several states, and the state will have the freedom to develop their own state as needed. This might support the development acceleration of each states. Assocciated to his position as the economy minister, Nadjmoeddin had suggested formation and procurement of some development fund exclusively to improve the trading and shipment in the amount of 5 million gulden (Gde Agung, 1985: 85-87). That was for advancing the natives sailing business that had been build when establishing ROEPELIN.

The effort that had been started by Najamuddin daeng Malewa in the 1930s to improve the native sails, had shows its advantages at around 1947. The Dutch East Indies government finally formed an collective ship owner authority. Initially was Maskapai Kapal Sulawesi Selatan (MKSS), that will alter its name to Perusahaan Pelayaran Sulawesi Selatan (PPSS) and Pelayaran Rakyat Indonesia (PERINDO) in Manado, North Sulawesi.

According to him, to improve the political development, must be preceded by the strong economy development. His dream was to put Indonesia in the appropriate position in the economy development. Therefore, the long term goal to create a middenstand could be achieved. Nadjamoeddin daeng Malewa view to further the economy development can be studied from the following speech of his quoted below:

...Kewadjiban kita ialah mengoeatkan dan mendjahterakan Negara Indonesia Timoer. Tujuan kita ialah menaikkan tingkat kemadjoean dan kema'moeran dari ra'yat banyak. Toedjoean kita ialah menghapoeskan keadaan yang tidak sama terhadap lain-lain Negara agar soepaya kita tidak sadja mendjadi parter yang sama harga menoeroet hoekoem tetapi djoega yang sama harga didalam hal ekonomis, financieel dan culkturee.

Our obligation is to strengthen and to provide welfare for Negara Indonesia Timur. Our goal is to improve the development and welfare of the people. Our 
goal is to eliminate the the condition that differentiate us from other country, that we may be the equal partner, not only according to the law, but also economically, financially, and culturally (Harian Oentoek Negara Indonesia Timoer, dated 24 April 1947).

\section{Conclusion}

Basically, Nadjamoedding nationality ideas in South Sulawesi may be simplified into three main ideas. First, the unity. The unity here means the elimination of ethnical borders amongst many Indonesian nations that will be institusionalized in an organization or political party. This is what Nadjemoeddin considered as the foundation of national identity. Second, education. To develop the education for the natives is very important as themain gate to open the knowledge to achive a better future. Therefore the society would be more aware to any change around them. Third, the economy base. Economy is the vital part of a nation to be a strong and independent nation and stands equally to the other nations. 


\section{REFERENCES}

Chaniago. (2002). Menuju Negara kesatuan Republik Indonesia: Peranan Pemimpin Lokal Dalam Dinamika Politik di Sulawesi selatan dan Sumatra Timur 1950. Disertasi UGM. Tidak Diterbitkan

Dick, H.W. (1990). Industri Pelayaran Indonesia Kompetisi dan Regulasi. J akarta: LP3ES.

Harvey, B. S. Pemberontakan Kahar Muzakkar Dari Tradisi Ke DI/TII. J akarta: Grafiti Pers.

Hobsbawm, E. J . (1992). Nasionalisme Menjelang Abad XXI. J ogjakarta: Tiara Wacana,

Gde AGung, I.D. (1985). Dari Negara Indonesia Timur Ke Republik Indonesia Serikat, J ogjakarta: Gadjah Mada University Press.

Kohn, H. (1984). Nasionalisme Arti dan Sejarahnya, J akarta: Erlangga.

Rasyid, A. (2007). Kopra makassar Perebutan Pusat dan Daerah Kajian Sejarah Politik Ekonomi Regional di Indonesia, Jakarta: Yayasan Obor Indonesia.

Pawiloy, S. (1987). Sejarah Perjuangan Angkatan 45 di Sulawesi Selatan (17 Agustus 1945 - 17 Agustus 1950), Ujungpandang: Dewan Harian Daerah (DHD) Angkatan 45 Provinsi Sulawesi Selatan, 1987.

Shiraishi, T. (1997). Zaman Bergerak: Radikalisme Rakyat di J awa 1912-1926, J akarta: Pustaka Utama Grafiti.

Bottomore. (2006). Elite dan Masyarakat, J akarta: Akbar Tandjung Institute

Sutherland, H. (1983). Terbentuknya Sebuah Elite Birokrasi. Jakarta: Sinar harapan,

\section{Paper, Magazine, Archieve}

"Djawaban Pemerintah terhadap Pemandangan Oemoem dari AnggotaAnggota Parlemen, Pidato P.J.M. Nadjamoeddin dg. Malewa-Perdana Menteri", Number Reg. 8 (Archieve Office of South Sulawesi Government, Makassar).

Barisan Kita: No. 2, Pebruari 1931 Year I; No. 7, September 1931, Year I; Number.2,

30 January 1932 Year II; Number 5, March 1932, Year II; Number 6, April 1932, Year II; Number 7, May 1932, Year II. 
Negara Baroe, Date 24 April 1947.

Pemberita Makassar, Kamis 7 desember 1939, Number 256, Second sheet. Soeara Parindra: Nomor I, J anuari 1936, Year I; Number I, May 1936, Year I Soelawesi, Number 25, 22 September 1934, Year I

Suara Perdamaian, Number 2, J uly 1930 Year I.

"Boeton Bangoen dari Tidoernja” In Barisan Kita, Number 5-6, July-August 1931 Year I

“Perdjoeangan Kebangsaan”, Suara Perdamaian, No.1 March 1931,Year I.

Hadidja Nadjamoeddin, "Taman Keputrian”, Barisan Kita, No.3-4, 15 and 29 February

1932, Year II

Handels Vereeniging "Makassar” Jaar Verslag over 1929-1930, Celebes: Drukkerig

Makassar

L. Mars, "Pergoeroean Kebangsaan", Barisan Kita No. 5,6 J uly- August 1931 Year I Nadjamoeddin daeng Malewa, Manifes Politik, Negara Baroe, 24 April 1947. Nadjamoeddin Daeng Malewa, "Sepandjang Pesisir SelebesSelatan", Pemberita

Makassar, Tueasday 4 February 1941, Number 26 Second sheet.

Nadjamoeddin Daeng Malewa, "Sepandjang Pesisir Selebes-Selatan", Pemberita Makassar, Thursday, 5 February 1941, Number 26, YearXXXIX, Second sheet.

Nadjamoeddin Daeng Malewa, "Sepandjang Pesisir Selebes-Selatan", Pemberita Makassar, Monday, 17 March 1941, Number 60, Year XXXIX, Second sheet. Nadjamoeddin Daengmalewa “DaengTaleleSchool”, Pemberita Makassar, Saturday

10 February 1940, Year XXXVIII, Number 34 , Second sheet.

"Tjara K.P.M. Mengalahkan Saingannja”, Soelawesi, Saturday 15 December 1934, Nomor 44,Year I

"Persatuan Selebes Selatan Keterangan Azas", Pemberita Makassar, 25 July 1939, Number 166, YearXXXVII, Second sheet.

"Politiek", Barisan Kita, Number 3-4, 15 dan 29 February 1932, Yearll

"Roch Pelajaran di Soelawesi Selatan", Soelawesi, Number 3, 21 April 1934 Year I, 